\title{
Targeting astrocytes in bipolar disorder
}

DOI:

10.1586/14737175.2016.1171144

\section{Document Version}

Accepted author manuscript

Link to publication record in Manchester Research Explorer

\section{Citation for published version (APA):}

Peng, L., Li, B., \& Verkhratsky, A. (2016). Targeting astrocytes in bipolar disorder. Expert Review of Neurotherapeutics, 16(6), 649-657. https://doi.org/10.1586/14737175.2016.1171144

\section{Published in:}

Expert Review of Neurotherapeutics

\section{Citing this paper}

Please note that where the full-text provided on Manchester Research Explorer is the Author Accepted Manuscript or Proof version this may differ from the final Published version. If citing, it is advised that you check and use the publisher's definitive version.

\section{General rights}

Copyright and moral rights for the publications made accessible in the Research Explorer are retained by the authors and/or other copyright owners and it is a condition of accessing publications that users recognise and abide by the legal requirements associated with these rights.

\section{Takedown policy}

If you believe that this document breaches copyright please refer to the University of Manchester's Takedown Procedures [http://man.ac.uk/04Y6Bo] or contact uml.scholarlycommunications@manchester.ac.uk providing relevant details, so we can investigate your claim.

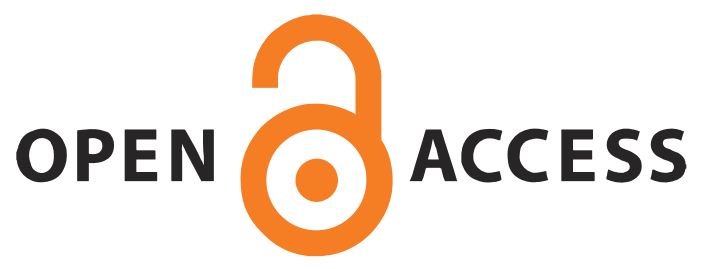




\section{Expert Review of Neurotherapeutics}

\section{Targeting astrocytes in bipolar disorder}

\section{Liang Peng, Baoman Li \& Alexei Verkhratsky}

To cite this article: Liang Peng, Baoman Li \& Alexei Verkhratsky (2016): Targeting astrocytes in bipolar disorder, Expert Review of Neurotherapeutics, DOI: 10.1586/14737175.2016.1171144

To link to this article: http://dx.doi.org/10.1586/14737175.2016.1171144

Accepted author version posted online: 25 Mar 2016.

Submit your article to this journal $\pi$

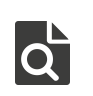

View related articles

View Crossmark data \lceil 
Publisher: Taylor \& Francis

Journal: Expert Review of Neurotherapeutics

DOI: $10.1586 / 14737175.2016 .1171144$

\section{Review}

\section{Targeting astrocytes in bipolar disorder}

\section{Liang Peng ${ }^{1}$, B aoman $\mathrm{Li}^{1}$ and A lexei Verkhratsky ${ }^{2,3,4}$}

${ }^{1} \mathrm{~L}$ aboratory of $\mathrm{M}$ etabolic Brain Diseases, Institute of $M$ etabolic Disease R esearch and Drug Development, China M edical U niversity, Shenyang, P. R. China, ${ }^{2}$ Faculty of $L$ ife Science, The U niversity of $M$ anchester, $M$ anchester, UK, ${ }^{3} A$ chucarro Center for Neuroscience, IKER B A SQUE, B asque Foundation for Science, 48011 Bilbao, Spain $\&$ Department of Neurosciences, U niversity of the B asque Country UPV/EHU and CIBERNED, Leioa, Spain; ${ }^{4}$ University of Nizhny N ovgorod, Nizhny N ovgorod 603022, Russia.

Send correspondence to:

Professor Liang Peng, $L$ aboratory of B rain M etabolic Diseases, Institute of M etabolic Disease Research and Drug D evelopment, China M edical U niversity, N o. 92 B eier Road, Heping District, Shenyang, P.R . China. e-mail: hkkid08@yahoo.com

OR

Professor A lexei Verkhratsky

Faculty of Life Science,

The U niversity of $\mathrm{M}$ anchester, $M$ anchester, UK email: A lexej.Verkhratsky@ manchester.ac.uk 


\begin{abstract}
A strocytes are homeostatic cells of the central nervous system, which are critical for development and maintenance of synaptic transmission and hence of synaptically connected neuronal ensembles. Astrocytic densities are reduced in bipolar disorder, and therefore deficient astroglial function may contribute to overall disbalance in neurotransmission and to pathological evolution. Classical anti-bipolar drugs (lithium salts, valproic acid and carbamazepine) affect expression of astroglial genes and modify astroglial signalling and homeostatic cascades. Many effects of both antidepressant and anti-bipolar drugs are exerted through regulation of glutamate homeostasis and glutamatergic transmission, through $\mathrm{K}^{+}$buffering, through regulation of cal cium-dependent phospholipase $\mathrm{A}_{2}$ (that controls metabolism of arachidonic acid) or through $\mathrm{Ca}^{2+}$ homeostatic and signalling pathways. Sometimes anti-depressant and anti-bipolar drugs exert opposite effects, and some effects on gene expression in drug treated animals are opposite in neurones vs. astrocytes. Changes in the intracellular $\mathrm{pH}$ induced by anti-bipolar drugs affect uptake of myo-inositol and thereby signalling via inositoltrisphosphate $\left(\mathrm{InSP}_{3}\right)$, this being in accord with one of the main theories of mechanism of action for these drugs.
\end{abstract}

Key words: astrocytes; bipolar disorder; mechanism of drug action 


\section{Introduction: Astroglia in synaptic transmission}

Synaptic connectivity lies at the very core of the functional nervous system, and impairments of synaptically connected neuronal networks underlie neuropathological evolution. Psychiatric diseases can be broadly regarded as pathological remodelling of synaptic connectivity and disbalance of neurotransmission in the brain [1-3]. This neurochemical disbalance affects not only transmission through excitatory (glutamatergic) and inhibitory (mostly GABA ergic) synapses but modifies the action of other systems mediated by serotonin, dopamine or adenosine [4,5].

The human brain contains in excess of 15 trillions of chemical synapses, which come in many guises. Nonetheless the majority (60 to 70\%) share the common architecture being composed of several cellular elements, and thus often being defined as a tri- or tetra- or multipartite synapses [6-10]. The cellular compartments forming the synapse are represented by (i) the presynaptic terminal, (ii) the postsynaptic neuronal part, (iii) the perisynaptic astroglial process, (iv) the microglial process that periodically contacts the synapse and (v) the extracellular matrix $[8,10,11]$. There is a clear distribution of functions between different components of the central synapse. In the presynaptic terminal the neurotransmitter vesicles concentrate, and specific protein machinery ascertains rapid vesicular release of these neurotransmitters following electrical excitation. The postsynaptic neuronal compartment (often associated with dendritic spines) is mainly concerned with reception of neurotransmitters (and hence bear appropriate neurotransmitter receptors) as well as with synaptic plasticity mediated by multiple enzymatic cascades that affect neurotransmitter receptors densities or control morphological postsynaptic remodelling $[12,13]$. Extracellular matrix present in the synaptic cleft and surrounding synaptic compartments regulates both pre- and postsynaptic elements [14]. Central synapses are regularly surveyed by microglial process that, if needed, prune synaptic contacts thus offering another level of plastic remodelling of neuronal networks [11]. Finally the multipartite synapses are closely enwrapped by astroglial perisynaptic processes, which form the "astroglial cradle" that controls all aspects of synaptic life, from synaptogenesis to synaptic maturation, maintenance and extinction $[10,15,16]$.

Through multiple transporters densely populating perisynaptic astroglial membranes, astrocyte regulates all fundamental aspects of synaptic cleft homeostasis $[10,17]$. These transporters (many of which are regulated by astroglial $\mathrm{Na}^{+}$signalling [18]) control extracellular potassium, regulate extracellular $\mathrm{pH}$, provide scavengers of reactive oxygen species and maintain the turnover and homeostasis of main neurotransmitters including glutamate, GABA and adenosine $[19,20]$. Most of glutamate $(\sim 80 \%)$, released in the course of synaptic transmission in the CNS is removed through accumulation into astrocytes; the latter being mediated by astroglia-specific plasmalemmal glutamate transporters EAAT1/SLC1A3 and EAAT2/SL C1A 2 (excitatory amino acid transporters 1 and 2). These transporters are $\mathrm{Na}^{+}$dependent; transport of a single glutamate molecule is associated with an influx 
of three $\mathrm{Na}^{+}$ions, one $\mathrm{H}^{+}$ion and efflux of one $\mathrm{K}^{+}$ion [21]. Part of glutamate accumulated by astrocytes is converted into glutamine by astroglia-specific enzyme glutamine synthetase, which is also fundamental for nitrogen metabolism [22,23]. Glutamine subsequently is transported back to neurones where it serves as an obligatory precursor for glutamate and GABA; this system generally known as glutamate-glutamine and GABA-glutamine shuttle. Thus astroglial compartment is critical for maintenance of glutamatergic and GABA-ergic transmissions and hence it defines the balance between excitation and inhibition in the brain; impairments of astroglial control over synaptic connectivity may therefore be fundamental for development of psychiatric diseases.

\section{Astroglia in bipolar disorder}

Glial cell numbers in the brain from patients of bipolar disorders are decreased [24-26]. This coincides with evidence for excessive activity of the glutamatergic system which has been well established in brains of bipolar patients by magnetic resonance imaging [25,27-29], and may be indicative of decreased glial glutamate homeostatic capacity. Administration of riluzole, a drug increasing expression and activity of glutamate transporters in astrocytes and hence increasing their glutamate clearance [30] modifies glutamine/glutamate metabolism, improves glutamatergic transmission in patients suffering from bipolar disorder [31] and ameliorates disease symptoms [32], again suggesting underlying astrocytic glutamatergic dysfunction. In mood disorders, serum levels of astroglia-specific biomarker S100 protein are increased, although it is more significant in major depression than bipolar disorder [33]. Serum levels of S100 protein are is thought to reflect active secretion by astrocytes rather than their damage.

Three classical anti-bipolar drugs, lithium salts, valproic acid (VPA) and carbamazepine (CBZ) differ in their chemical structures and in acute drug effects. Lithium salt is effective in treating mania episode and bipolar depression, and in preventing relapses [34], whereas carbamazepine and valproic acids are used for treating mania episodes $[35,36]$. Of note, classic anti-bipolar drugs have to be administered for a couple of weeks before their therapeutic action becomes manifest. in studies of mechanisms(s) of action for anti-bipolar drugs it is therefore important to determine the effects that are not immediate but only appear after chronic administration.

\section{Astroglial actions of anti-bipolar drugs}

\subsection{Inositol turnover}

The myo-inositol is constantly degraded or released from cells, and a continuous resupply is needed, partly from the diet and slow transfer across the blood-brain barrier [37] and partly by de novo synthesis, which in the brain occurs in the 
vasculature [38]. Although it is often assumed that myo-inositol in the brain is exclusively found in astrocytes $[39,40]$, this may be an oversimplification. Treatment of cultured mouse astrocytes with $1 \mathrm{mM} \mathrm{LiCl}$ for 8 days inhibited uptake of $50 \mu \mathrm{M}$ inositol, whereas acute administration of lithium had no effect [41]. Chronic treatment of cultured rat astrocytes with any of the three anti-bipolar drugs (lithium, CBZ, and V PA) had a similar effect [42]. Suppression of the uptake was reflected by decreased inositol contents (measured as equilibrated $\left[{ }^{3} \mathrm{H}\right]$ ]inositol spaces) in human astrocytoma cells [43]. The opposite effects at different myo-inositol concentrations, for example increase of uptake at lower myo-inositol concentrations but decrease at higher concentrations, might be explained on the basis of the presence of two inositol transporters in astrocytes, the high-affinity $\mathrm{Na}^{+}$-dependent myo-inositol transporter (SMIT), accounting for the most of the uptake at $25 \mu \mathrm{M}$ inositol, and the lower-affinity $\mathrm{H}^{+}$-dependent HMIT, accounting for the most of the uptake at $50 \mu \mathrm{M}$ inositol [44]. Since increased intracellular $\mathrm{pH}\left(\mathrm{pH}_{\mathrm{i}}\right)$ is known to stimulate SM IT but inhibit HMIT, the effect of anti-bipolar drugs might be explained by a gradually developing intracellular alkalinisation. This was confirmed later by experiments of $\left[{ }^{3} \mathrm{H}\right]$ myo-inositol uptake in astrocytes at different myo-inositol concentrations and $\mathrm{pH}$ and by different myo-inositol transporters [45].

\subsection{Ins $P_{3}$ signalling}

Therapeutic effects of lithium in bipolar disorder are often ascribed to the depletion of myo-inositol following $\mathrm{Li}^{+}$-induced non-competitive inhibition of inositolphosphate hydrolysis (see above). The InsP 3 produced by PLC degrades to myo-inositol by inositol phosphatases, whereas DAG is converted to phosphatidate and condensed with cytidine triphosphate to form cytidine monophosphoryl-phosphatidate (CM P-PA), which together with myo-inositol re-generates $\mathrm{PIP}_{2}$. Since $\mathrm{Li}^{+}$inhibits formation of inositol from InsP $\mathrm{P}_{3}$, it decreases the regeneration of $\mathrm{PIP}_{2}$, and thus occludes PLC pathway. The $\left[\mathrm{C}^{2+}\right]_{i}$ response to noradrenaline in cultured astrocytes is, indeed, reduced by chronic, but not acute, exposure to $\mathrm{Li}^{+}$[46]. Neither CBZ, nor VPA, however, inhibited inositol phosphate hydrolysis. This raises the question if they might reduce / $\mathrm{NS}_{3}$ formation by other means; such as for example by reducing cellular uptake of inositol [43,44].

\subsection{Cytosolic pH}

Chronic treatment with any of the three antibipolar drugs increased cytosolic $\mathrm{pH}\left(\mathrm{pH}_{\mathrm{i}}\right)$ in astrocytes measured by a fluorometric method $[47,48]$. The acid-controlling transporters that exists in almost all cell types, including neurones and astrocytes [49] are the $\mathrm{Na}^{+}-\mathrm{H}^{+}$exchanger (NHE) and the $\mathrm{Na}^{+} /$bicarbonate co-transporter $\mathrm{NBCel}$. There are seven subtypes of HNE, NHE1 - NHE7. Cultured astrocytes from rat hippocampus [50] and from mouse cerebral cortex [47] express NHE1. Chronic treatment with the therapeutically rel evant $\mathrm{Li}^{+}$concentration of $1 \mathrm{mM}$ for 2 or 3 weeks increased $\mathrm{pH}_{\mathrm{i}}$ by $\sim 0.10$, whereas $0.5 \mathrm{mM}$ was ineffective, and $2 \mathrm{mM}$ caused an even 
larger increase [47]. The alkalinisation resulted from acute stimulation of NHE by extracellular $\mathrm{Li}^{+}$, which was directly demonstrated after acid load with $\mathrm{NH}_{4} \mathrm{Cl}$ in the absence of $\mathrm{HCO}_{3}{ }^{-}$in the incubation buffer in order to exclude the contribution of $\mathrm{Na} / \mathrm{HCO}_{3}$ co-transporters (NBC). The changes in $\mathrm{pH}_{\mathrm{i}}$ occurred only in chronic treatment, this being longer at the lower $\mathrm{Li}^{+}$concentrations.

The $\mathrm{NBC}$ co-transports $\mathrm{Na}^{+}$with $\mathrm{HCO}_{3}{ }^{-}$and functions either as acid-loader or acid-extruder, according to the $\mathrm{Na}^{+}: \mathrm{HCO}_{3}{ }^{-}$stoichiometry [49]. The $\mathrm{NBCel}$ subtype with a 1:2 $\mathrm{Na}^{+}: \mathrm{HCO}_{3}{ }^{-}$stoichiometry is the major transporter in astroglia. The activity of $\mathrm{NBCel}$ is $\mathrm{HCO}_{3}{ }^{-}$- and $\mathrm{Na}^{+}$-dependent. The increased $\mathrm{pH}_{i}$ in cultured astrocytes following chronic treatment with therapeutically relevant concentrations of $C B Z$ or $V P A$ results from an increase in the activity of $\mathrm{NBCel}$. Carbamazepine or val proate up-regulated expression of NBCel mRNA and protein in astrocytes as revealed by RT-PCR and Western blotting $[48,51]$.

\subsection{GluK2 kainate receptors}

Reduced expression of GluK 2 in the brains from bipolar patients, most of whom had received medication, has been described in the entorhinal cortex [52] and in the hippocampus [53]. Chronic treatment of primary cultures of astrocytes with $\mathrm{Li}^{+}, \mathrm{VPA}$ or CBZ at clinically relevant concentrations down-regulated gene expression of GluK 2 (Fig. 1), but had no effect on other GluK receptors [54]. These effects are not associated with drug toxicity, since oxcarbazepine (OCBZ), a keto-congener of CBZ used in bipolar disorder [55] with less side effects than CBZ [56], has similar effect as CBZ, whereas topiramate, an anticonvulsant with no anti-bipolar effect, does not affect GluK 2 expression [54]. Two weeks of intraperitoneal injection of CBZ, decreased expression of GRIK 2 gene (the gene encoding GluK 2 protein) in the brain in vivo. These observations may be of special interest, since the GRIK 2 resides in a genetic linkage region (6q21) associated with bipolar disorder [57].

\subsection{Phosphopipase A2 (cPLA $\left.A_{2}\right)$}

The $\mathrm{Ca}^{2+}$ dependent phospholipase $\mathrm{A}_{2}$ (CPLA 2 IVA) mobilises arachidonic acid, which is a precursor for a multiple physiologically active molecules, including prostaglandins and inflammatory agents [58]. Expression of IVA subtype of CPLA 2 (85 kD; CPLA $2 a)$ mRNA and protein is increased in bipolar patients, without significant effects of anti-bipolar medication [59]. Conversely, chronic treatment with $\mathrm{Li}^{+}$for 6 weeks decreases the expression of $\mathrm{CPLA} \mathrm{A}_{2}$ in the rat brain, whereas $\mathrm{Li}^{+}$has no effect on two other types of PLA $A_{2}, S P L A_{2}$ and $\mathrm{PLL}_{2}$ [60-62]. This down-regulation is also specific for the IVA subtype of $\mathrm{CPLA}_{2}$. Similar results were found in rat chronically treated with CBZ [63], whereas chronic treatment with VPA does not influence CPL $A_{2}$ [64].

In contrast to the findings in vivo, each of the three anti-bipolar drugs induced both 
up- and down-regulation of $\mathrm{CPLA}{ }_{2}$ gene expression in astrocytes in primary culture. Two weeks of treatment with $\mathrm{Li}^{+}$at a high concentration $(2 \mathrm{mM})$ caused an up-regulation of protein expression of $\mathrm{CPLA} \mathrm{A}_{2}$ in astrocytes, whereas 1 week of treatment had no effect and treatment for 3 or 4 weeks down-regulated expression. At lower concentrations $(0.5$ and $0.25 \mathrm{mM}), \mathrm{Li}^{+}$increased expression of $\mathrm{CPLA} \mathrm{A}_{2}$ protein. Similarly, CBZ or VPA transiently increased CPLA 2 expression; this effect occurred more rapidly at higher concentrations (Fig. 2). This effect is specific for anti-bipolar drug, since topiramate was ineffective. In freshly isolated and FACS-sorted cells from mice expressing neurone or astrocyte-specific markers two weeks of treatment with CBZ up-regulated CPLA $A_{2}$ in astrocytes but down-regulated it in neurones [51].

\subsection{TRPC1 channels}

A strocytes are electrically non-excitable cells, which employ transient fluctuations of intracellular concentration of cations, $\mathrm{Ca}^{2+}, \mathrm{Na}^{+}$and possibly $\mathrm{K}^{+}$as a substrate for their excitability [65-69]. Astroglial calcium signalling is mainly mediated by activation of inositol-1,4,5-trisphoshate receptors ( $\left(\operatorname{InSP}_{3} R s\right)$ localised in the membrane of the endoplasmic reticulum with subsequent activation of store-operated $\mathrm{Ca}^{2+}$ entry $[67,68]$. In astrocytes the store operated $\mathrm{Ca}^{2+}$ influx provided by TRPC $1 / 4 / 5$ channels [67]. Chronic treatment with any of the 3 conventional anti-bipolar drugs $\mathrm{Li}^{+}$, carbamazepine or val proic acid decreases mRNA and protein expression of the TRPC1 (Fig. 3), which results in the inhibition of store-operated $\mathrm{Ca}^{2+}$ entry [70]. This is consistent with observations in platelets and lymphocytes from bipolar patients as well as with outcome of chronic treatment of lymphoblast cell lines derived from such patients with $\mathrm{Li}^{+}$. The store-operated $\mathrm{Ca}^{2+}$ entry activated following thapsigargin-induced depletion of intracellular $\mathrm{Ca}^{2+}$ was increased in platelets and lymphocytes from patients suffering from bipolar disorder [71],as well as in lymphoblast cell Nines derived from bipolar patients [72], treatment of these cells $\mathrm{Li}^{+}$treatment for 7 days reduced store-operated $\mathrm{Ca}^{2+}$ influx [73].

\subsection{Glutamate release}

A strocytes produce and secrete numerous neuroactive agents, that include classical neurotransmitters (glutamate, ATP, or GABA). Release of neuroactive substances from astrocytes is mediated by several molecular pathways that include diffusion through plasmalemmal channels, translocation by membrane transporters and exocytotic vesicular release [74]. The latter is regulated by cytosolic $\mathrm{Ca}^{2+}$ signals. Chronic treatment $\mathrm{Li}^{+}$, carbamazepine and val proic acid decreased glutamate release from astrocytes induced by transient exposure to ATP (which activated purinoceptors) or to $45 \mathrm{mM} \mathrm{K}^{+}$(which depolarised cell membrane to $\sim 30 \mathrm{mV}$ ). This suppression of glutamate release which may alleviate the hyperactivity of the glutamatergic transmission in the brain of patients with bipolar disorders and thus contribute the underlying mechanism of drug action [75]. 


\subsection{Na/K-ATPase (NKA)}

The role for NKA dysfunction in bipolar disorder was suggested almost 50 years ago $[76,77]$. The $\alpha 1$ subunit of NKA is expressed in both neurones and glia, the $\alpha 2$ subunit is primarily expressed in astrocytes, whereas the $\alpha 3$ subunit is expressed only in neurones [78]. A significantly lower NKA density has been found in the brain tissue from bipolar disorder patients compared to patients who suffered from major depression or schizophrenia, with no difference in a subtype expression in synaptosomal fractions [79], although there were indication for a decrease of the $\alpha 2$ gene expression [80]. Using transgenic mice carrying neurone or astrocyte-specific fluorescent markers (FVB/NTg(GFAP-GFP)14M es/J or B 6.Cg-Tg(Thy1-Y FPH)2]rs/] animals) from which neurones and astrocytes were isolated and FACS-sorted, demonstrated that $\alpha 2$ expression was up-regulated in astrocytes and neurones, the $\alpha 1$ was selectively increased in neurones, whereas $\alpha 3$ remained unchanged after administration of CBZ by intraperitoneal injection for 2 weeks [81]. This suggests, again, altered $\mathrm{K}^{+}$homeostasis in mood disorders.

\subsection{Elongation protein zeta 1 (FEZ1)}

The FEZ1 is a mammalian ortholog of UNC-76, a protein initially found in the nematode Caenorhabditis elegans. The UNC-76 is associated with neuronal development and could contribute to various neuropathologies [82] In mammals, the FEZ1 is expressed exclusively in the brain, in neurones and astroglia, and is found in the cytoplasm as well as in the nucleus. The FEZ1 interacts with various proteins related to cytoskeleton network, transport of cargoes, regulation of the cell cycle, and retrovirus propagation In the neuropsychiatric context the FEZ1 is known as an interacting partner of the schizophrenia-related protein disrupted in schizophrenia 1 (DISC1), and FEZ1-deficient mice presented abnormal behaviours [82]. In human astrocyte-derived cell line U-87 M G, four anti-bipolar drugs, lithium, valproic acid, carbamazepine, and Vamotrigine up-regulated FEZ1 mRNA and protein expression [83].

\subsection{Other receptors, enzymes and proteins}

A $n$ increase in expression of adenosine $A_{1}$ receptor was suggested to have potential neuroprotective effect in the mechanisms of the antidepressive effects of chronic treatment with carbamazepine [84]. In primary astrocyte cultures from different regions of the rat brain, $C B Z$ treatment for 10 days had no effect on adenosine $A_{1}$-receptor mRNA expression in cultures with high basal $A_{1}$-receptor mRNA levels, but increased $A_{1}$-receptor $m R N A$ in cultures exhibiting low basal $A_{1}$-receptor $m R N A$ levels [85].

The glycogen synthase kinase 3 (GSK -3) is an enzyme that was first discovered to deactivate glycogen synthase, which converts glucose to glycogen; subsequently it 
was found that GSK-3 mediates multiple signalling pathways, including AKT and Wnt signalling [86]. It is well established that lithium is an inhibitor of GSK-3 [86]. In astrocytes, lithium inhibits phosphoglucomutase (PGM) thus decreasing glycogen synthesis [87] and reduced the lipopolysaccharide (LPS)-induced secretion of pro-inflammatory cytokines [88]. Chronic treatment with lithium also increased expression of B cell CLL/lymphoma 2 protein, an anti-apoptotic factor bcl-2, vascular endothelial growth factor (VEGF), brain-derived growth factor (BDNF) and glial cell-derived neurotrophic factor (GDNF) in astrocytes in vitro [89-91]. In the in vivo brain, lithium treatment significantly increased GFAP expression in rat hippocampus [92].

Treatment with VPA up-regulated the mRNA expression of two post-synaptic cell adhesion molecules (neuroligin-1 and neuregulin-1) and two extracellular matrices (neuronal pentraxin-1and thrombospondin-3) in primary rat astrocyte cultures in a time- and concentration-dependent manner [93], suggesting that VPA might affect the synaptic excitatory/inhibitory balance through its effect on astrocytes. In cultured astrocytes VPA (but not carbamazepine or lamotrigine) evoked the strongest global chromatin modifications, including hyperacetylation of histone $\mathrm{H} 3 / \mathrm{H} 4,2 \mathrm{M} \mathrm{eH} 3 \mathrm{~K} 9$ and DNA demethylation that were reflected at the glutamate transporter GLT-1 promoter and enhanced transcription of this astroglia-specific gene [94]. In addition, VPA (but not lithium or carbamazepine) inhibits substance P-induced activation of protein kinase $C$ epsilon and expression of the substance $P$ receptor in astrocytes; of note the substance $P$ was suggested to contribute to the etiopathology of affective disorders [95].

\section{EXPERT COMMENTARY}

A strocytes, due to their unique position as central homeostatic elements in the brain, are fundamental for proper function of synaptically connected neuronal networks. Decrease in astroglial synaptic coverage due to the reduced astroglial density, which is observed in bipolar disorder, may be a critical factor underlying deregulation of neurotransmission responsible for this type of psychiatric pathology. The mechanism of action of anti-bipolar drags was always associated with neurones. Nonetheless, all three major anti-bipolar drugs, lithium salts, valproic acid and carbamazepine affect astroglial receptors, signalling cascades and homeostatic function. In particular the anti-bipolar drugs affect glutamate and potassium homeostasis associated with astrocytes. It remains unclear how these astro-centric mechanisms contribute to overall therapeutic action, although further investigations of astroglial cells as targets in the context of bipolar disease may lead to a development of new drugs and therapeutic strategies.

\section{FIVE YEAR VIEW}

The pathological potential of astrocytes, and specifically the role of astroglial cells in 
neuropsychiatric disorders, received attention of scientific community only very recently $[25,26,96,97]$. Experiments performed mostly in astrocytes in vitro, in primary cultures, have demonstrated that classic anti-bipolar drugs regulate expression of multiple genes in astrocytes and affect astroglia-associated homeostatic systems. Identification of astroglial systems linked to bipolar disorders and recognition of molecular targets of anti-bipolar agents represents the next fundamental step towards positioning astrocytes within the context of neuropsychiatric pathology. Of particular interest are the astroglial effects of lithium salts. A nother important development is the translation of the data obtained in laboratory animals towards human pathology, which require introduction of new disease models both in yitro and in vivo. These fundamental studies open new horizons in development of astroglia-specific therapies.

\section{KEY ISSUES}

Astrocytes are central elements of the synaptic transmission and neurochemical balance in the brain

In bipolar disorders astrocytes show signs of atrophy and their number decreases which may affect brain homeostasis and underlie deregulation of neurotransmission.

Classical anti-bipolar drugs affect astroglial receptors, signalling cascades and homeostatic functions.

Specific targeting of astroglia may represent a novel strategy in developing anti-bipolar therapies.

\section{DECLARATION OF INTEREST}

This study was supported by Grant No. 31171036 to L Peng from the National Natural Science Foundation of China. A Verkhratsky was supported in part by the grant (agreement from A ugust $272013 \cdot 02 \cdot \bullet$.49.21.0003) between The M inistry of Education and Science of the Russian Federation and Lobachevsky State University of Nizhny Novgorod and by the grant of the Russian Scientific Foundation - 14-15-00633. The authors have no other relevant affiliations or financial involvement with any organization or entity with a financial interest in or financial conflict with the subject matter or materials discussed in the manuscript apart from those disclosed. 


\section{References}

Reference annotations

* Of interest

** of considerable interest

1. Pittenger $C$, Duman RS. Stress, depression, and neuroplasticity: a convergence of mechanisms. Neuropsychopharmacology, 33(1), 88-109 (2008).

2. Racagni G, Popoli M. Cellular and molecular mechanisms in the long-term action of antidepressants. Dialogues Clin Neurosci, 10(4), 385-400 (2008).

3. **Sanacora G, Treccani G, Popoli M. Towards a glutamate hypothesis of depression: an emerging frontier of neuropsychopharmacology for mood disorders. Neuropharmacology, 62(1), 63-77 (2012).

Comprehensive overview of the glutamatergic mechanisms of depression.

4. $*$ K aster MP, Machado NJ, Silva HB et al. Caffeine acts through neuronal adenosine $A_{2 A}$ receptors to prevent mood and memory dysfunction triggered by chronic stress. Proc Natl Acad Sci US A, 112(25), 7833-7838 (2015).

Demonstration of the role of $A_{1}$ receptors in mood dysfunction and the efficacy of caffeine in threeating cognitive impairments.

5. M atos $M$, Shen $H Y, A$ ugusto $E$ et al. Deletion of A denosine A Receptors from A strocytes Disrupts Glutamate Homeostasis Leading to Psychomotor and Cognitive Impairment: Relevance to Schizophrenia. Biol Psychiatry, 78(11), 763-774 (2015).

6. $\quad * *$ A raque A, Parpura V, Sanzgiri RP, Haydon PG. Tripartite synapses: glia, the unacknowledged partner. Trends Neurosci, 22(5), 208-215 (1999).

First conceptualisation of the tripartiute synapse concept.

7. Derouiche A, A nlauf E, A umann G, Muhlstadt B, Lavialle M. A natomical aspects of glia-synapse interaction: the perisynaptic glial sheath consists of a special ized astrocyte compartment. J Physiol Paris, 96(3-4), 177-182 (2002).

8. Dityatev A, Rusakov DA. Molecular signals of plasticity at the tetrapartite synapse. Curr Opin Neurobiol, 21(2), 353-359 (2011).

9. Halassa MM, Fellin T, Haydon PG. The tripartite synapse: roles for gliotransmission in health and disease. Trends Mol Med, 13(2), 54-63 (2007).

10. $* *$ Verkhratsky A, Nedergaard M. A stroglial cradle in the life of the synapse. Philos Trans R Soc Lond B Biol Sci, 369(1654), 20130595 (2014).

The decsription of the astroglial cradle with enphasis on multiple homeostatic astroglial mechanisms. 
11. *K ettenmann $\mathrm{H}, \mathrm{K}$ irchhoff $\mathrm{F}$, Verkhratsky A. Microglia: new roles for the synaptic stripper. Neuron, 77(1), 10-18 (2013).

A comprehensive overview of the role of microglia in shaping neuronal synaptic connections.

12. Colbran RJ. Thematic M inireview Series: M olecular M echanisms of Synaptic Plasticity. J Biol Chem, 290(48), 28594-28595 (2015).

13. Bailey $\mathrm{CH}, \mathrm{K}$ andel $\mathrm{ER}$, Harris KM. Structural Components of Synaptic Plasticity and Memory Consolidation. Cold Spring Harb Perspect Biol, 7(7), a021758 (2015).

14. Senkov O, Andjus P, Radenovic L, Soriano E, Dityatev A. Neural ECM molecules in synaptic plasticity, learning, and memory. Prog Brain Res, 214, 53-80 (2014).

15. *Eroglu C, Barres BA. Regulation of synaptic connectivity by glia. Nature, 468(7321), 223-231 (2010).

Detailed overview of multiple astrolgia-dependent mechanisms regulating synaptigenesis and synaptic maturatiuon.

16. Nedergaard $M$, Verkhratsky A. A rtifact versus reality--how astrocytes contribute to synaptic events. Glia, 60(7), 1013-1023 (2012).

17. Parpura V, Verkhratsky A. Homeostatic function of astrocytes: $\mathrm{Ca}^{2+}$ and $\mathrm{Na}^{+}$ signalling. Transl Neurosci, 3(4), 334-344 (2012).

18. Kirischuk S, Parpura V, Verkhratsky A. Sodium dynamics: another key to astroglial excitability? Trends Neurosci, 35(8), 497-506 (2012).

19. Boison D, Chen JF, Fredholm BB. A denosine signaling and function in glial cells. Cell Death Differ, 17(7), 1071-1082 (2010).

20. Danbolt N C. Glutamate uptake. Progr. Neurobiol., 65, 1-105 (2001).

21. Zhou Y, Danbolt NC. GABA and Glutamate Transporters in Brain. Front Endocrinol (Lausanne), 4, 165 (2013).

22. Martinez-Hernandez A, Bell KP, Norenberg MD. Glutamine synthetase: glial localization in brain. Science, 195(4284), 1356-1358 (1977).

23. Rose CF, Verkhratsky A, Parpura V. A strocyte glutamine synthetase: pivotal in health and disease. Biochem Soc Trans, 41(6), 1518-1524 (2013).

24. Ongur D, Drevets WC, Price JL. Glial reduction in the subgenual prefrontal cortex in mood disorders. Proc Natl Acad Sci U S A, 95(22), 13290-13295 (1998).

25. Ongur D, Jensen JE, Prescot AP et al. Abnormal glutamatergic neurotransmission and neuronal-glial interactions in acute mania. Biol Psychiatry, 64(8), 718-726 (2008).

26. **Rajkowska G. Postmortem studies in mood disorders indicate altered numbers of neurons and glial cells. Biol Psychiatry, 48(8), 766-777 (2000). 
Detailed early desription of decrease in astroglial density in mood disorders.

27. Michael N, Erfurth A, Ohrmann $\mathrm{P}$ et al. A cute mania is accompanied by elevated glutamate/glutamine levels within the left dorsolateral prefrontal cortex. Psychopharmacology (Berl), 168(3), 344-346 (2003).

28. Chen $\mathrm{CH}$, Suckling $\mathrm{J}, \mathrm{O}$ oi $\mathrm{C}$ et al. A longitudinal $\mathrm{fM} \mathrm{RI}$ study of the manic and euthymic states of bipolar disorder. Bipolar Disord, 12(3), 344-347 (2010).

29. Eastwood SL, Harrison PJ. Markers of glutamate synaptic transmission and plasticity are increased in the anterior cingulate cortex in bipolar disorder. Biol Psychiatry, 67(11), 1010-1016 (2010).

30. *Carbone M, Duty S, Rattray M. Riluzole elevates GLT-1 activity and levels in striatal astrocytes. Neurochem Int, 60(1), 31-38 (2012).

An experimental demostration of increased expression of glutamate tarnsporters in astrocytes by riluzole.

31. Brennan BP, Hudson JI, J ensen JE et al. Rapid enhancement of glutamatergic neurotransmission in bipolar depression following treatment with riluzole. Neuropsychopharmacology, 35(3), 834-846 (2010).

32. Zarate CA, Manji HK. Riluzole in psychiatry: a systematic review of the literature. Expert Opin Drug Metab Toxicol, 4(9), 1223-1234 (2008).

33. Schroeter M L, Sacher J, Steiner J, Schoenknecht P, M ueller K. Serum S100B represents a new biomarker for mood disorders. Curr Drug Targets, 14(11), 1237-1248 (2013).

34. Brown K M , Tracy DK. Lithium: the pharmacodynamic actions of the amazing ion. Ther Adv Psychopharmacol, 3(3), 163-176 (2013).

35. Post RM, K etter TA, Uhde $T, B$ allenger J C. Thirty years of clinical experience with carbamazepine in the treatment of bipolar illness: principles and practice. CNS Drugs, 21(1), 47-71 (2007).

36. Macritchie K, Geddes JR, Scott J, Haslam D, de Lima M, Goodwin G. Valproate for acute mood episodes in bipolar disorder. Cochrane Database Syst Rev, (1), CD 004052 (2003).

37. Spector R, Lorenzo AV. The origin of myo-inositol in brain, cerebrospinal fluid and choroid plexus. J Neurochem, 25(3), 353-354 (1975).

38. Wong Y H, Kalmbach SJ, Hartman BK, Sherman WR. Immunohistochemical staining and enzyme activity measurements show myo-inositol-1-phosphate synthase to be localized in the vasculature of brain. $J$ Neurochem, 48(5), 1434-1442 (1987).

39. Glanville NT, Byers DM, Cook HW, Spence M W, Palmer FB. Differences in the metabolism of inositol and phosphoinositides by cultured cells of neuronal and glial origin. Biochim Biophys Acta, 1004(2), 169-179 (1989).

40. B rand A, Richter-L andsberg C, L eibfritz D. M ultinuclear N M R studies on the energy metabolism of glial and neuronal cells. Dev Neurosci, 15(3-5), 289-298 (1993). 
41. Wolfson M, Hertz E, Belmaker RH, Hertz L. Chronic treatment with lithium and pretreatment with excess inositol reduce inositol pool size in astrocytes by different mechanisms. Brain Res, 787(1), 34-40 (1998).

42. Lubrich $B$, van Calker $D$. Inhibition of the high affinity myo-inositol transport system: a common mechanism of action of antibipolar drugs? Neuropsychopharmacology, 21(4), 519-529 (1999).

43. Hertz $L$, Chen $Y$, Bersudsky $Y$, Wolfson $M$. Shared effects of all three conventional anti-bipolar drugs on the phosphoinositide system in astrocytes. In: Non-Neuronal Cells of the Nervous System: Function and Dysfunction. Hertz, L (Ed. (Elsevier Science, A msterdam, 2004) 1033-1048.

44. Wolfson $M$, Bersudsky $Y$, Zinger $E$, Simkin $M$, Belmaker RH, Hertz L. Chronic treatment of human astrocytoma cells with lithium, carbamazepine or valproic acid decreases inositol uptake at high inositol concentrations but increases it at low inositol concentrations. Brain Res, 855(1), 158-161 (2000).

45. Fu H, Li B, Hertz L, Peng L. Contributions in astrocytes of SM IT 1/2 and HM IT to myo-inositol uptake at different concentrations and pH. Neurochem Int, 61(2), 187-194 (2012).

46. Chen $\mathrm{Y}, \mathrm{H}$ ertz $\mathrm{L}$. Inhibition of noradrenaline stimulated increase in $\left[\mathrm{Ca}^{2+}\right]_{i}$ in cultured astrocytes by chronic treatment with a therapeutically relevant lithium concentration. Brain Res, 711(1-2), 245-248 (1996).

47. Song D, Du T, Li B et al. A strocytic alkalinization by therapeutically relevant lithium concentrations: implications for myo-inositol depletion. Psychopharmacology (Berl), 200(2), 187-195 (2008).

48. Song $D, M$ an $Y, L i B, X u Y$, Hertz $L$, Peng $L$. Comparison between drug-induced and $\mathrm{K}^{+}$-induced changes in molar acid extrusion fluxes $\left(\mathrm{JH}^{+}\right)$ and in energy consumption rates in astrocytes. Neurochem Res, 38(11), 2364-2374 (2013).

49. McAlear SD, Bevensee MO. A cysteine-scanning mutagenesis study of transmembrane domain 8 of the electrogenic sodium/bicarbonate cotransporter NBCe1. S Biol Chem, 281(43), 32417-32427 (2006).

50. Pizzonia J $H$, Ransom BR, Pappas CA. Characterization of $\mathrm{Na}^{+} / \mathrm{H}^{+}$exchange activity in cultured rat hippocampal astrocytes. $J$ Neurosci Res, 44(2), 191-198 (1996).

51. Song D, Li B, Yan E et al. Chronic treatment with anti-bipolar drugs causes intracellular alkalinization in astrocytes, altering their functions. Neurochem Res, 37(11), 2524-2540 (2012).

52. Beneyto $M$, Kristiansen LV, Oni-Orisan A, McCullumsmith RE, $M$ eador-Woodruff JH. A bnormal glutamate receptor expression in the medial temporal lobe in schizophrenia and mood disorders. Neuropsychopharmacology, 32(9), 1888-1902 (2007).

53. Benes FM, Todtenkopf MS, Kostoulakos P. GluR5,6,7 subunit immunoreactivity on apical pyramidal cell dendrites in hippocampus of schizophrenics and manic depressives. Hippocampus, 11(5), $482-491$ (2001).

54. Li B, Zhang S, Li M, Zhang H, Hertz L, Peng L. D own-regulation of GluK2 
kainate receptor expression by chronic treatment with mood-stabilizing anti-convul sants or lithium in cultured astrocytes and brain, but not in neurons. Neuropharmacology, 57(4), 375-385 (2009).

55. Popova E, L eighton C, B ernabarre A, B ernardo M, Vieta E. Oxcarbazepine in the treatment of bipolar and schizoaffective disorders. Expert Rev Neurother, 7(6), 617-626 (2007).

56. Gualtieri CT, Johnson LG. Comparative neurocognitive effects of 5 psychotropic anticonvulsants and lithium. MedGenMed, 8(3), 46 (2006).

57. Schulze TG, Buervenich S, Badner JA et al. Loci on chromosomes $6 q$ and $6 p$ interact to increase susceptibility to bipolar affective disorder in the national institute of mental health genetics initiative pedigrees. Biol Psychiatry, 56(1), 18-23 (2004).

58. *Hertz L, Song D, Li B, Yan E, Peng L. Importance of inflammatory molecules', but not necessarily of inflammation, in the pathophysiology of bipolar disorder and in the mechanisms of action of anti-bipolar drugs. Neurology, Psychiatry and Brain Research, 19, 174-179 (2013).

An overview of glial mechansims and secereted pro-inflammatory molecules in pathogenesis of bipolar disorder.

59. Kim HW, Rapoport SI, Rao JS. Altered arachidonic acid cascade enzymes in postmortem brain from bipolar disorder patients. Mol Psychiatry, 16(4), 419-428 (2011).

60. Basselin M, Chang L, Seemann R, Bell JM, Rapoport SI. Chronic lithium administration to rats selectively modifies $5-\mathrm{HT}_{2 \mathrm{~A} / 2 \mathrm{C}}$ receptor-mediated brain signaling via arachidonic acid. Neuropsychopharmacology, 30(3), 461-472 (2005).

61. Rintala J, Seemann R, Chandrasekaran K et al. $85 \mathrm{kDa}$ cytosolic phospholipase $A_{2}$ is a target for chronic lithium in rat brain. Neuroreport, 10(18), 3887-3890 (1999).

62. Weerasinghe GR, Rapoport SI, B osetti F. The effect of chronic lithium on arachidonic acid release and metabolism in rat brain does not involve secretory phospholipase A2 or lipoxygenase/cytochrome P450 pathways. Brain Res Bull, 63(6), 485-489 (2004).

63. Ghelardoni S, Tomita YA, Bell JM, Rapoport SI, Bosetti F. Chronic carbamazepine selectively downregulates cytosolic phospholipase $A_{2}$ expression and cyclooxygenase activity in rat brain. Biol Psychiatry, 56(4), 248-254 (2004).

64. Chang M C, Contreras M A, Rosenberger TA, Rintala JJ, B ell JM, Rapoport SI. Chronic val proate treatment decreases the in vivo turnover of arachidonic acid in brain phospholipids: a possible common effect of mood stabilizers. $J$ Neurochem, 77(3), 796-803 (2001).

65. Rose CR, Verkhratsky A. Principles of sodium homeostasis and sodium signalling in astroglia. Glia, in press (2016). 
66. Verkhratsky A, Orkand RK, K ettenmann H. Glial calcium: homeostasis and signaling function. Physiol Rev, 78(1), 99-141 (1998).

67. Verkhratsky A, Rodriguez J , Parpura V. Calcium signalling in astroglia. Mol Cell Endocrinol, 353(1-2), 45-56 (2012).

68. Verkhratsky A, Parpura V. Store-operated calcium entry in neuroglia. Neurosci Bull, 30(1), 125-133 (2014).

69. Zorec R, A raque A, Carmignoto G, Haydon PG, Verkhratsky A, Parpura V. Astroglial excitability and gliotransmission: an appraisal of $\mathrm{Ca}^{2+}$ as a signalling route. ASN Neuro, 4(2), e00080 (2012).

70. Yan E, Li B, Gu L, Hertz L, Peng L. Mechanisms for L-channel-mediated increase in $\left[\mathrm{Ca}^{2+}\right]_{i}$ and its reduction by anti-bipolar drugs in cultured astrocytes combined with its mRNA expression in freshly isolated cells support the importance of astrocytic L-channels. Cell Calcium, 54(5), 335-342 (2013).

71. Hough C, Lu SJ, Davis CL, Chuang DM, Post RM. Elevated basal and thapsigargin-stimulated intracellular calcium of platelets and lymphocytes from bipolar affective disorder patients measured by a fluorometric microassay. Biol Psychiatry, 46(2), 247-255 (1999).

72. Perova T, Wasserman MJ, Li PP, Warsh JJ. Hyperactive intracellular calcium dynamics in B lymphoblasts from patients with bipolar I disorder. Int $J$ Neuropsychopharmacol, 11(2), 185-196 (2008).

73. Wasserman MJ, Corson TW, Sibony D et al. Chronic lithium treatment attenuates intracellular calcium mobilization. Neuropsychopharmacology, 29(4), 759-769 (2004).

74. **Verkhratsky A, M atteoli M, Parpura V, M othet J-P, Zorec R. A strocytes as secretory cells of the central nervous system: idiosyncrasies of vesicular secretion. EMBO J., 35(3), 239-257, (2016).

Introduction of the concept of astrocytes as secretory cells in the central nervous system.

75. Liu Z, Song D, Yan E, Verkhratsky A, Peng L. Chronic treatment with anti-bipolar drugs suppresses glutamate release from astroglial cultures. Amino Acids, 47(5), 1045-1051 (2015).

76. Shaw DM . M ineral metabolism, mania, and melancholia. $\mathrm{Br}$ Med J, 2(5508), 262-267 (1966).

77. Coppen A, Shaw DM, Malleson A, Costain R. M ineral metabolism in mania. Br Med J, 1(5479), 71-75 (1966).

78. McGrail KM, Phillips JM, Sweadner KJ. Immunofluorescent localization of three $\mathrm{Na}, \mathrm{K}$-ATPase isozymes in the rat central nervous system: both neurons and glia can express more than one Na,K -ATPase. $J$ Neurosci, 11(2), 381-391 (1991).

79. Goldstein I, Levy T, Galili D et al. Involvement of $\mathrm{Na}^{+}, \mathrm{K}^{+}$-ATPase and endogenous digitalis-like compounds in depressive disorders. Biol Psychiatry, 
60(5), 491-499 (2006).

80. Rose AM, M ellett BJ, Valdes R, Jr. et al. $\alpha 2$ isoform of the $\mathrm{Na}, \mathrm{K}$-adenosine triphosphatase is reduced in temporal cortex of bipolar individuals. Biol Psychiatry, 44(9), 892-897 (1998).

81. Li B, Hertz L, Peng L. Cell-specific mRNA alterations in $\mathrm{Na}^{+}, \mathrm{K}^{+}$-ATPase alpha and beta isoforms and FXYD in mice treated chronically with carbamazepine, an anti-bipolar drug. Neurochem Res, 38(4), 834-841 (2013).

82. Maturana $A D$, Fujita $T, K$ uroda $S$. Functions of fasciculation and elongation protein zeta-1 (FEZ1) in the brain. ScientificWorldJournal, 10, 1646-1654 (2010).

83. $\mathrm{YuZ}, \mathrm{Ono} \mathrm{C}, \mathrm{Kim} \mathrm{HB}$ et al. Four mood stabilizers commonly induce FEZ1 expression in human astrocytes. Bipolar Disord, 13(5-6), 486-499 (2011).

84. Biber K, Lubrich B, Fiebich BL, Boddeke HW, van Calker D. Interleukin-6 enhances expression of adenosine $A_{1}$ receptor mRNA and signaling in cultured rat cortical astrocytes and brain slices. Neuropsychopharmacology, 24(1), 86-96 (2001).

85. Biber K, Fiebich BL, Gebicke-Harter $P$, yan Calker D. Carbamazepine-induced upregulation of adenosine $A_{1}$-receptors in astrocyte cultures affects coupling to the phosphoinositol signaling pathway. Neuropsychopharmacology, 20(3), 271-278 (1999).

86. Can A, Schulze TG, Gould TD. Molecular actions and clinical pharmacogenetics of lithium therapy. Pharmacol Biochem Behav, 123, 3-16 (2014).

87. Souza Ade A, da Silva GS, Velez BS, Santoro AB, Montero-Lomeli M. Glycogen synthesis in brain and astrocytes is inhibited by chronic lithium treatment. Neurosci Lett, 482(2), 128-132 (2010).

88. Green HF, Nolan X M. GSK-3 mediates the release of IL -1 $1 \beta$, TNF- $\alpha$ and IL-10 from cortical glia. Neurochem Int, 61(5), 666-671 (2012).

89. E mamghoreishi $M$, Keshavarz $M, N$ ekooeian $A A$. A cute and chronic effects of lithium on BDNF and GDNF mRNA and protein levels in rat primary neuronal, astroglial and neuroastroglia cultures. Iran J Basic Med Sci, 18(3), 240-246 (2015).

90. Guo S, A rai K, Stins M F, Chuang DM, Lo EH. Lithium upregulates vascular endothelial growth factor in brain endothelial cells and astrocytes. Stroke, 40(2), 652-655 (2009).

91. Keshavarz M, Emamghoreishi M, Nekooeian AA, J JW, Zare HR. Increased bcl-2 Protein Levels in Rat Primary Astrocyte Culture Following Chronic Lithium Treatment. Iran J Med Sci, 38(3), 255-262 (2013).

92. Rocha $E$, Rodnight R. Chronic administration of lithium chloride increases immunodetectable glial fibrillary acidic protein in the rat hippocampus. $J$ Neurochem, 63(4), 1582-1584 (1994).

93. Wang CC, Chen PS, Hsu CW, Wu SJ, Lin CT, Gean PW. Valproic acid mediates the synaptic excitatory/inhibitory balance through astrocytes--a preliminary study. Prog Neuropsychopharmacol Biol Psychiatry, 37(1), 
111-120 (2012).

94. Perisic T, Zimmermann N, Kirmeier $\mathrm{T}$ et al. Val proate and amitriptyline exert common and divergent influences on global and gene promoter-specific chromatin modifications in rat primary astrocytes. Neuropsychopharmacology, 35(3), 792-805 (2010).

95. Lieb K, Treffurth $Y$, Hamke M, A kundi RS, von K leinsorgen M, Fiebich BL. Valproic acid inhibits substance $P$-induced activation of protein kinase $C$ epsilon and expression of the substance P receptor. $J$ Neurochem, 86(1), 69-76 (2003).

96. Verkhratsky A, Rodriguez JJ, Steardo L. A strogliopathology: a central element of neuropsychiatric diseases? Neuroscientist, 20(6), 576-588 (2014).

97. Verkhratsky A, Sofroniew MV, Messing A et al. Neurological diseases as primary gliopathies: a reassessment of neurocentrism. ASN Neuro, 4(3), e00082 (2012).

98. $\mathrm{Li} B, \mathrm{Gu} \mathrm{L}$, Zhang $\mathrm{H}$ et al. Up-regulation of $\mathrm{CPLA} 2$ gene expression in astrocytes by all three conventional anti-bipolar drugs is drug-specific and enzyme-specific. Psychopharmacology (Berl), 194(3), 333-345 (2007). 


\section{Figure legend}

Figure 1. Effect of chronic treatment with $C B Z$ on the expression of astroglial GluK 2 receptors.

A: A representative experiment showing Western blots for GluK 2 and for ${ }^{2}$-actin (a house-keeping protein), in control cultures and cultures treated with CBZ for 1 day, 3 days, 1 week, 2 weeks, 3 weeks, and 4 weeks.

B: Average (means \pm SEM, three samples from three independent experiments) changes in expression ratio GluK 2 and ${ }^{2}$-actin for control cultures, and cultures treated with 25 or $50 \mu \mathrm{M} \mathrm{CBZ;} * \mathrm{P}<0.05$ vs. control cultures from the same batch and treatment period.

Protein expression was measured by immunoblotting of GluK 2 in primary cultures of mouse astrocytes treated for up to 4 weeks with 25 or $50 \mu \mathrm{M} \mathrm{CBZ}$. Primary cultures of astrocytes were prepared from the neopallia of the cerebral hemispheres of newborn CD-1 mice, and grown in Dulbecco's M inimum Essential Medium (DM EM). A fter 2 weeks in vitro, $0.25 \mathrm{mM}$ dibutyryl cyclic A M P (dB CAM P) was included in the medium, which led to a morphological and functional differentiation. These cultures are highly enriched in astrocytes ( $>95 \%$ purity of glial fibrillary protein- and glutamine synthetase-expressing astrocytes). A fter 3 weeks in vitro, cells exposed to 0

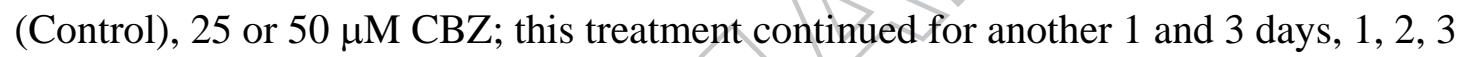
or 4 weeks. Specific binding was detected by horseradish peroxidise-conjugated secondary antibody.

Reprinted from Neuropharmacology, v. 57, Li, B ., Zhang, S., Li, M ., Zhang, H., Hertz, L. \& Peng, L. Down-regulation of GluK 2 kainate receptor expression by chronic treatment with mood-stabilizing anti-convulsants or lithium in cultured astrocytes and brain, but not in neurons, p. 375-385, Copyright (2009) with permission from Elsevier. 
A

CBZ

CBZ
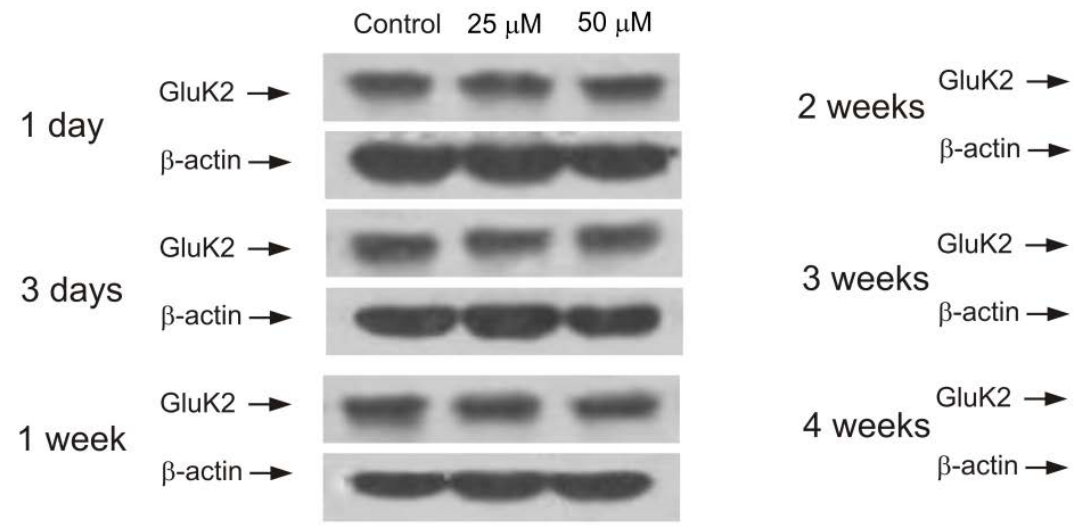

B

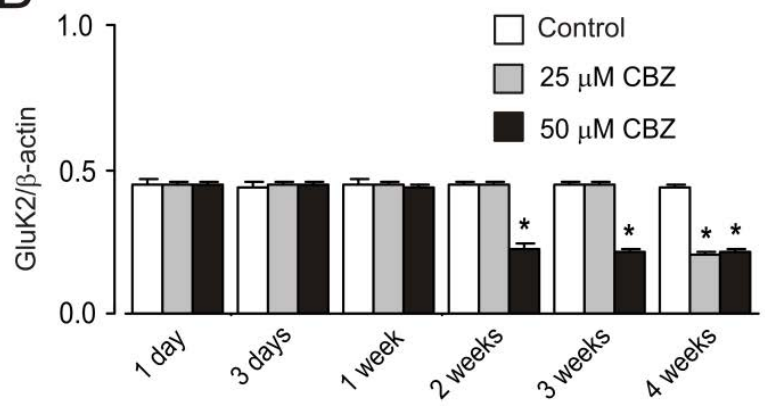

Fig.1 
Figure 2. Effect of chronic treatment with $C B Z$ on the expression of astroglial GluK2 phospholipase $\mathrm{A}_{2 \mathrm{a}}$.

A: A representative experiment showing Western blots for $\mathrm{CPLA}_{2 a}$ and for ${ }^{2}$-actin (a house-keeping protein), in control cultures and cultures treated with CBZ for 1, 2, 3, or 4 weeks.

B: Average (means $\pm \mathrm{SEM}$, four samples from four independent experiments) changes in expression ratio CPLA ${ }_{2 a}$ and ${ }^{2}$-actin for control cultures, and cultures treated with 25 or $50 \mu \mathrm{M} \mathrm{CBZ;} * \mathrm{P}<0.05$ vs. control cultures from the same batch and treatment period.

Protein expression was measured by immunoblotting of $\mathrm{CPLA} \mathrm{A}_{2 a}$ in primary cultures of mouse astrocytes treated for 1 to 4 week with 25 or $50 \mu \mathrm{M} \mathrm{CBZ}$. Primary cultures of astrocytes were prepared as described in the legend to Fig. 1. A fter 3 weeks in vitro, cells were exposed to 0 (Control), 25 or $50 \mu \mathrm{M} \mathrm{CBZ}$; this treatment continued for another $1,2,3$, or 4 weeks. Specific binding was detected by horseradish peroxidise-conjugated secondary antibody.

Reprinted from Psychopharmacology (Berl), v. 194, Li, B., Gu, L., Zhang, H., Huang, J., Chen, Y., Hertz, L. \& Peng, L. U p-regulation of CPLA 2 gene expression in astrocytes by all three conventional anti-bipolar drugs is drug-specific and enzyme-specific. p. 333-345, Copyright (2007) with permission of Springer .

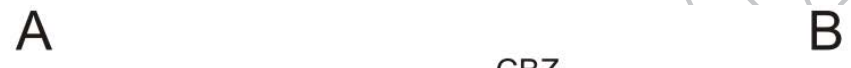

Control $25 \mu \mathrm{M} \quad 50 \mu \mathrm{M}$

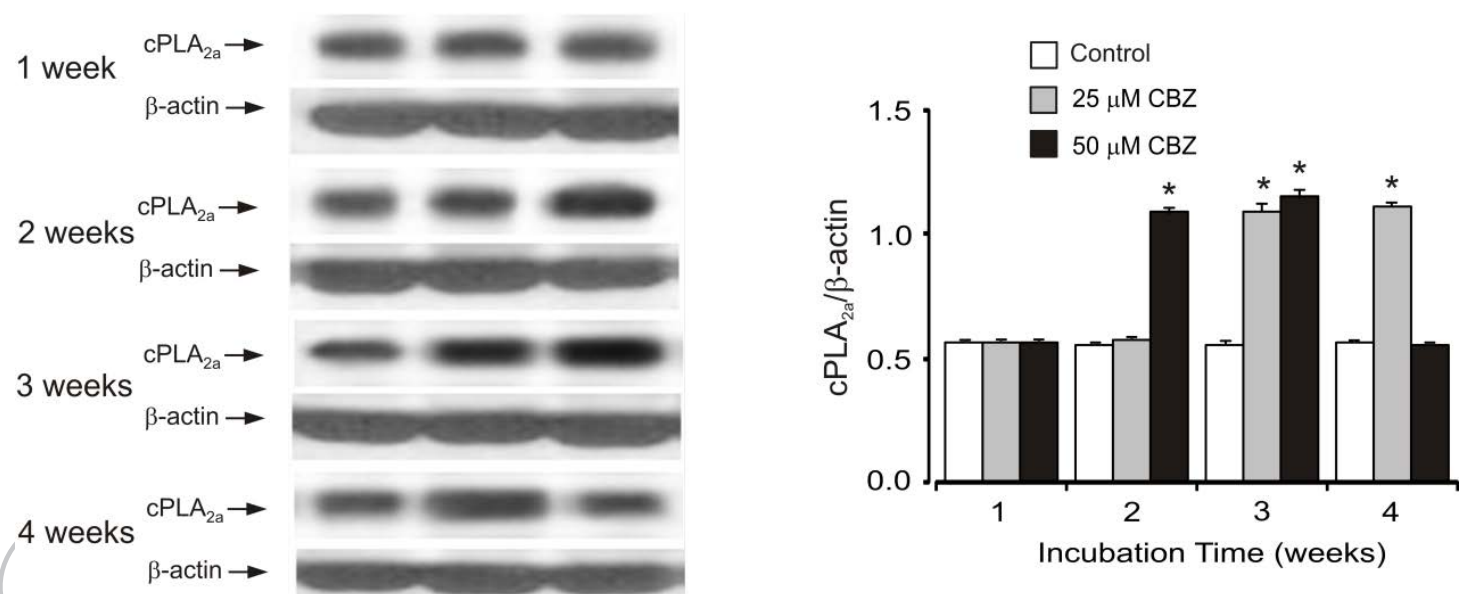

Fig.2 
Figure. 3. Effect of chronic treatment with antibipolar drugs on the expression of astroglial TRPC1 channels.

A: A representative experiment showing Western blots for TRPC1 and for ${ }^{2}$-actin (a house-keeping protein), in control cultures and cultures treated with $\mathrm{Li}^{+}-, \mathrm{CBZ}-$ or VPA.

B: Average (means \pm SEM, three samples from three independent experiments) changes in expression ratio TRPC1 and ${ }^{2}$-actin for control cultures, and cultures treated with $\mathrm{Li}^{+}-$, CBZ- or VPA; $* \mathrm{P}<0.05$ vs. control cultures from the same batch and treatment period.

Protein expression was measured by immunoblotting of TRPC1 in primary cultures of mouse astrocytes treated for 2 weeks with $1 \mathrm{mM} \mathrm{Li}{ }^{+}, 50 \mu \mathrm{M} \mathrm{CBZ}$ or $1 \mathrm{mMVPA}$.

Reprinted from Cell Calcium, v. 54 Yan, E., Li, B., Gu, L., Hertz, L. \& Peng, L. $2013 \mathrm{M}$ echanisms for $\mathrm{L}$-channel-mediated increase in $\left[\mathrm{Ca}^{2+}\right]_{i}$ and its reduction by anti-bipolar drugs in cultured astrocytes combined with its MRNA expression in freshly isolated cells support the importance of astrocytic L-channels, p. 335-342, Copyright (2013), with permission from Elsevier.

A

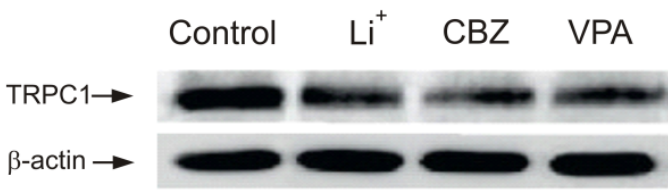

B

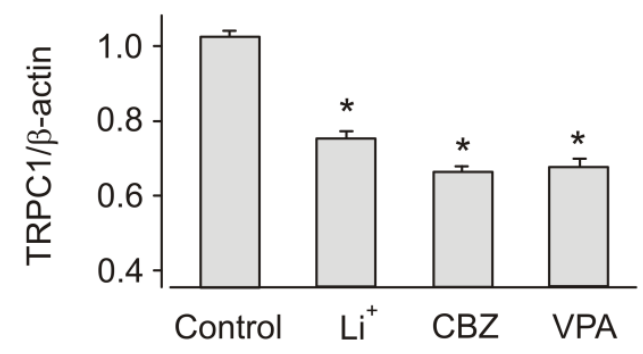

Fig.3 